\title{
Conflicts among peers in the playground in a group of Spanish elementary schools
}

\section{ABSTRACT}

1.
This study aimed to analyse and explore through systematic observation the conflicts that occur among peers during the playground in elementary schools in Spain. The study followed a non-experimental descriptive design and all conflicts were observed in their natural context of 44 schools. Among the 1691 conflicts detected in a sample of 2529 students, significant differences were found among the different types of conflicts (verbal, physical, social exclusion and sexual harassment), which depended on the course and sex of the protagonists. Furthermore, a different pattern emerged in the reactions that other peers and teachers had to the initial conflicts. Additionally, findings were consistent with the findings in previous studies in the literature regarding the need to train and prepare teachers to prevent future conflicts in the scholar context.

\section{INTRODUCTION}

During the past decades, there has been a renewed interest in social interactions and conflicts among children (Rubin et al. 2006; Laursen et al. 2001). Studies show that the school playground provides an important and unique context for analysing and learning about children's conflicts and disagreements

\section{KEYWORDS}

elementary school conflicts among peers playground reaction to conflict assertiveness teachers 
(Santa 2007). However, given its unstructured nature, the examination of the different kinds of conflicts is not easy, for neither researchers nor teachers (Félix et al. 2008; Rivers and Smith 1994).

At the same time, there is a wide consensus among researchers regarding the origin of such conflict behaviours. Contrary to what was commonly believed, it has been proven that the majority of conflicts appear due to a lack of a successful emotional management (Filella 2014; Keener and Leaman 2007). Thus, the best way to intervene and prevent conflicts is to train children into how to be more efficient at an emotional level. This makes it easier to avoid harsher consequences such as problems in the learning process, or even bullying (Basu and Mermillod 2011).

In order to tackle the particular causes and limited skills that enhance conflict situations, it is highly needed to understand conflict behaviours and how they are displayed in centres and schools, as well as which other variables may intervene.

According to previous literature, the most influential variables in conflict situations are sex and age (Ostrov and Crick 2007; Murray-Close and Ostrov 2009). Several studies emphasize that the highest incidence of conflicts takes place between the age of 9 to 14 years, when coercion is often the most used strategy to solve conflicts (Laursenet al. 2001; Pelegrini and Long 2002). However, it is often observed that younger children live more conflicts on the playground due to their immaturity and their tendency to present more aggressive behaviour during conflict situations (Sidorowicz and Hair 2009). Regarding sex, studies show that boys exhibit a higher degree of physical agression, whereas girls tend to present more relational aggression (MurrayClose and Ostrov 2009; Toldos 2005).

In this same direction, the reaction of peers to the initial conflicts have been relatively little studied. Previous studies, though, point out that reactions are often different between boys and girls, though both show a tendency to reactive aggression at the first moment (Hay et al. 2011).

One further issue is how teachers manage the conflicts that appear in school. In this sense, it is safe to state that most teachers rarely intervene in conflict situations that take place in the playground and do not feel ready to deal with them (Escámez 2001; Simbulaet al. 2012; Van der Meulen et al. 2003). Escámez (2001), for instance, demonstrated that 57 per cent of the teaching staff did not feel ready to face the conflicts that appear in the classroom, while a striking 10 per cent of the teachers did not regard conflict situations in school as their responsibility. Nonetheless, teachers feel pressured to intervene when certain situations take place, for example, hitting, stealing or blackmailing, cases that may make them feel overwhelmed (Del Barrio et al. 2003).

Therefore, the causes and resolution of conflict situations in school cannot be understood without analysing the conflict phenomenon that is taking place in our centres and schools.

\section{OBJECTIVES}

The objective of the present article is to describe the types of conflicts occurring in the school playground, providing results for age and sex, and to shed some light on the underlying mechanisms of such behaviours. Furthermore, we want to explore if the initial conflicts predict certain reactions. Additionally, we aim to study the kind of intervention that teachers exhibit when conflict situations occur.

2.

3.

4.

5.

6.

7.

8.

9.

10.

11.

12.

13.

14.

15.

16.

17.

18.

19.

20.

21.

22.

23.

24.

25.

26.

27.

28.

29.

30.

31.

32.

33.

34.

35.

36.

37.

38.

39.

40.

41.

42.

43.

44.

45.

46.

47.

48.

49.

50.

51.

52. 
To classify conflicts, we will use the classification of the Defensordel Pueblo (2006) and Martín et al. (2003), which make a distinction between verbal aggression; physical aggression; social exclusion; and sexual harassment.

\section{METHODS}

\section{Sample and participants}

The sample comprised a total of 1691 peer conflicts experienced by students of 44 schools of elementary education in the city of Lleida (Spain). The total number of students participating in the study was 2529 (1548 boys [61.21 per cent] and 981 girls [38.79 per cent]).The average rate of conflicts registered every day was 4.8 conflicts per day.

\section{Instruments and Data sources}

The present non-experimental descriptive study was based on a systematic observation registration that was carried out by the students of the last course in Elementary Education at the University of Lleida (UdL). Students were specifically trained for the purpose and participated voluntarily in the study. The anecdotic registration used in this study had four dimensions: demographic data, description of the initial conflict, description of the reaction of the students to the initial conflict, and intervention. After the registration, the conflicts were categorized in four clusters: verbal aggression, physical aggression, social exclusion and breaking the rules of the school.

The observation took place during February 2014. During this period two graduate students, who were undergoing their training program, registered all the conflicts that occurred during a period of eight days in each one of the participant schools. They also registered those conflicts that were reported by the students.

In order to validate the systematic observation tool, several expert judges evaluated the reliability by using the Cronbach's $\alpha$ index, which resulted in a satisfactory result of 0.81 .

\section{RESULTS}

\section{Conflicts registered in the observation}

As can be seen in Table 1, a total of 1691 conflicts were observed, differentiating between cycle (age) and sex of the participants. The cycle in which more conflicts were observed was the initial one (6 to 8 years old). Interestingly, the lowest number of conflicts was observed when the children involved in the conflict had different ages.

Regarding the difference between sexes, we observed that when conflicts occur among peers of the same age, the highest percentage of conflicts registered is always between boys. However, contrary to that, in those conflicts that involved children of different ages, the highest percentage of occurrence was among boys and girls, that is, mixed.

The Chi-Square test was carried out to study the differences between cycles and conflicts among peers. Table 2 shows that conflicts among boys tend to be more physical, whereas conflicts among girls are mainly related to social exclusion. Regarding the cycles, it is important to note that during the initial cycle, physical conflicts were significantly more common, especially among 


\begin{tabular}{lcrrc}
\hline Grade & Sex & Frecuency & Percentage & Total cycle \\
Elementary & & & & \\
School in & & & & \\
Spain & & & & \\
\hline Initial Cycle & Boys & 292 & $17.3 \%$ & \\
(6-8y) & Girls & 158 & $9.3 \%$ & $n=636(37.6 \%)$ \\
& Mixed & 186 & $11.0 \%$ & \\
Medium Cycle & Boys & 186 & $11.0 \%$ & \\
(8-10y) & Girls & 141 & $8.3 \%$ & $n=447(26.4 \%)$ \\
& Mixed & 120 & $7.1 \%$ & \\
Highercycle & Boys & 153 & $9.0 \%$ & \\
$(10-12 y)$ & Girls & 67 & $4.0 \%$ & $n=315(18.6 \%)$ \\
& Mixed & 95 & $5.6 \%$ & \\
Mixedcyle & Boys & 111 & $6.6 \%$ & \\
$(6-12 y)$ & Girls & 40 & $2.4 \%$ & $n=293(17.3 \%)$ \\
& Mixed & 142 & $8.4 \%$ & \\
\hline Total & & $\mathbf{1 6 9 1}$ & $\mathbf{1 0 0 \%}$ & \\
\hline
\end{tabular}

Table 1: Descriptives of the sample regarding sex and grade $(\mathrm{n}=1691)$.

1. 2. 3. 4. 5. 6. 7. 8. 9. 10. 11. 12. 13. 14. 15.

boys. In contrast, in the medium cycle, the most frequent type of conflict was social exclusion, particularly among girls. All in all, social exclusion appeared to be the most recurrent type of conflict, especially among those situations that involve girls.

As a second part of the analysis, we studied the relationship between the conflicts that were initially registered and the reactions of the other peers to these situations (see Table 3). A Chi Square test was carried out to explore whether there was a relationship between these two variables. Interestingly, physical aggression tended to be responded with both a fresh aggression or, alternatively, asking for help, which is similar to what happens on breaking the rules. In a different manner, those children who faced verbal or psychological aggression tended to react by asking for help.

Finally, we carried a $\chi$ Square test to explore how the initial conflict determined which resolution strategy was adopted by the teachers. As Table 4 shows, the most applied strategy is the mediation role of the teacher in all kinds of initial conflicts, whereas the resolution strategy that was less employed was making the student say'sorry' on breaking the rules. Strikingly, psychological aggression was the type of conflict that registers less intervention from the teachers.

\section{DISCUSSION}

Coexistence in school inevitably leads to the emergence of conflicts. Olweus (1993), as a pioneer in the field, explained that conflicts lead to negative consequences for all those who live them. More recently, in an attempt to explain why these conflicts emerge and cause such devastating outcomes, several experts suggested that aggression does not occur due to a high hostility but due to a lack of adequate emotional management (Filella 2014; Ortega 2008). 


\begin{tabular}{|c|c|c|c|c|c|c|}
\hline \multirow{2}{*}{$\begin{array}{l}1 . \\
2 . \\
3 .\end{array}$} & \multirow[t]{2}{*}{ Type of conflict } & \multicolumn{3}{|c|}{ Sex } & \multirow[t]{2}{*}{ Total } & \multirow{2}{*}{$\begin{array}{c}\text { bilateral } \\
\text { Sig. }\end{array}$} \\
\hline & & Boys & Girls & Mixt & & \\
\hline \multirow{8}{*}{$\begin{array}{l}\text { Initial } \\
\text { Cycle }\end{array}$} & \multirow[t]{2}{*}{ Verbal } & 52 & 32 & 25 & \multirow[t]{2}{*}{109} & \multirow[t]{8}{*}{$p<0.001$} \\
\hline & & $17,8 \%$ & $20,3 \%$ & $13,4 \%$ & & \\
\hline & \multirow[t]{2}{*}{ Physical } & 127 & 29 & 79 & \multirow[t]{2}{*}{235} & \\
\hline & & $43,5 \%$ & $18,4 \%$ & $42,5 \%$ & & \\
\hline & \multirow[t]{2}{*}{ Social exclusion } & 74 & 85 & 51 & \multirow[t]{2}{*}{210} & \\
\hline & & $25,3 \%$ & $53,8 \%$ & $27,4 \%$ & & \\
\hline & \multirow[t]{2}{*}{ Norms } & 39 & 12 & 31 & \multirow[t]{2}{*}{82} & \\
\hline & & $13,4 \%$ & $7,6 \%$ & $16,7 \%$ & & \\
\hline \multirow{8}{*}{$\begin{array}{l}\text { Medium } \\
\text { cycle }\end{array}$} & \multirow[t]{2}{*}{ Verbal } & 47 & 33 & 22 & \multirow[t]{2}{*}{102} & \multirow[t]{8}{*}{$p<0.001$} \\
\hline & & $25,3 \%$ & $23,4 \%$ & $18,3 \%$ & & \\
\hline & \multirow[t]{2}{*}{ Physical } & 80 & 23 & 31 & \multirow[t]{2}{*}{134} & \\
\hline & & $43,0 \%$ & $16,3 \%$ & $25,8 \%$ & & \\
\hline & \multirow[t]{2}{*}{ Social exclusion } & 46 & 71 & 48 & \multirow[t]{2}{*}{165} & \\
\hline & & $24,7 \%$ & $50,4 \%$ & $40,0 \%$ & & \\
\hline & \multirow[t]{2}{*}{ Norms } & 13 & 14 & 19 & 46 & \\
\hline & & $7,0 \%$ & $9,9 \%$ & $15,8 \%$ & & \\
\hline Higher & Verbal & 34 & 23 & 33 & 90 & $p<0.001$ \\
\hline cycle & & $22,2 \%$ & $34,3 \%$ & $34,7 \%$ & & \\
\hline $\begin{array}{l}25 . \\
26 .\end{array}$ & Physical & 53 & 16 & 23 & 92 & \\
\hline 27. & & $34,6 \%$ & $23,9 \%$ & $24,2 \%$ & & \\
\hline 28. & Social exclusion & 33 & 27 & 30 & 90 & \\
\hline 29. & & $21,6 \%$ & $40,3 \%$ & $31,6 \%$ & & \\
\hline 30. & Norms & 33 & 1 & 9 & 43 & \\
\hline 31. & & $21,6 \%$ & $1,5 \%$ & $9,5 \%$ & & \\
\hline Mixtcyle & Verbal & 23 & 11 & 38 & 72 & $p=0.062$ \\
\hline $\begin{array}{l}33 . \\
34 .\end{array}$ & & $20,7 \%$ & $27,5 \%$ & $26,8 \%$ & & \\
\hline 35. & Physical & 43 & 5 & 37 & 85 & \\
\hline 36. & & $38,7 \%$ & $12,5 \%$ & $26,1 \%$ & & \\
\hline 37. & Social exclusion & 35 & 20 & 51 & 106 & \\
\hline 38. & act & $31,5 \%$ & $50,0 \%$ & $35,9 \%$ & & \\
\hline 39. & Norms & 10 & 4 & 16 & 30 & \\
\hline $\begin{array}{l}40 . \\
41\end{array}$ & & $9,0 \%$ & $10,0 \%$ & $11,3 \%$ & & \\
\hline Total & Verbal & 156 & 99 & 118 & 373 & $p<0.001$ \\
\hline 43. & & $21,0 \%$ & $24,4 \%$ & $21,7 \%$ & & \\
\hline 44. & Physical & 303 & 73 & 170 & 546 & \\
\hline 45. & & $40,8 \%$ & $18,0 \%$ & $31,3 \%$ & & \\
\hline 46. & Social exclusion & 188 & 203 & 180 & 571 & \\
\hline 47. & & $25,3 \%$ & $50,0 \%$ & $33,1 \%$ & & \\
\hline 48. & Norms & 95 & 31 & 75 & 201 & \\
\hline 50. & & $12,8 \%$ & $7,6 \%$ & $13,8 \%$ & & \\
\hline Total & Count & 742 & 406 & 543 & 1691 & \\
\hline
\end{tabular}

Table 2: Chi square indexes for the different conflicts regarding the cycle and the sex. 


\begin{tabular}{|c|c|c|c|c|c|c|c|c|}
\hline & \multicolumn{8}{|c|}{ Reaction to the initial conflict } \\
\hline & $\begin{array}{c}\text { Verbal } \\
\text { aggression }\end{array}$ & $\begin{array}{c}\text { Physical } \\
\text { aggression }\end{array}$ & $\begin{array}{l}\text { Psychological } \\
\text { aggression }\end{array}$ & $\begin{array}{l}\text { Breaking } \\
\text { rules }\end{array}$ & $\begin{array}{l}\text { Helpnessness } \\
\text { responese }\end{array}$ & $\begin{array}{l}\text { Asking } \\
\text { for help }\end{array}$ & $\begin{array}{c}\text { Doing } \\
\text { nothing }\end{array}$ & $\begin{array}{c}\text { Bilateral } \\
\text { Sig. }\end{array}$ \\
\hline \multicolumn{9}{|l|}{ Initialconflict } \\
\hline $\begin{array}{l}\text { Verbal } \\
\text { aggression }\end{array}$ & $\begin{array}{c}35 \\
(24 \%)\end{array}$ & $\begin{array}{c}29 \\
(13 \%)\end{array}$ & $\begin{array}{c}0 \\
(0 \%)\end{array}$ & $\begin{array}{c}0 \\
(0 \%)\end{array}$ & $\begin{array}{c}24 \\
(29 \%)\end{array}$ & $\begin{array}{c}58 \\
(16 \%)\end{array}$ & $\begin{array}{c}21 \\
(20 \%)\end{array}$ & $p<0.001$ \\
\hline $\begin{array}{l}\text { Physical } \\
\text { agression }\end{array}$ & $\begin{array}{c}20 \\
(14 \%)\end{array}$ & $\begin{array}{c}96 \\
(43 \%)\end{array}$ & $\begin{array}{c}3 \\
(14 \%)\end{array}$ & $\begin{array}{c}0 \\
(0 \%)\end{array}$ & $\begin{array}{c}27 \\
(33 \%)\end{array}$ & $\begin{array}{c}98 \\
(27 \%)\end{array}$ & $\begin{array}{c}41 \\
(40 \%)\end{array}$ & \\
\hline $\begin{array}{c}\text { Psychological } \\
\text { aggression }\end{array}$ & $\begin{array}{c}40 \\
(27 \%)\end{array}$ & $\begin{array}{c}31 \\
(14 \%)\end{array}$ & $\begin{array}{c}11 \\
(50 \%)\end{array}$ & $\begin{array}{c}1 \\
(100 \%)\end{array}$ & $\begin{array}{c}29 \\
(35 \%)\end{array}$ & $\begin{array}{c}161 \\
(44 \%)\end{array}$ & $\begin{array}{c}34 \\
(33 \%)\end{array}$ & \\
\hline $\begin{array}{l}\text { Breaking } \\
\text { rules }\end{array}$ & $\begin{array}{c}51 \\
(35 \%) \\
\end{array}$ & $\begin{array}{c}66 \\
(30 \%) \\
\end{array}$ & $\begin{array}{c}8 \\
(36 \%) \\
\end{array}$ & $\begin{array}{c}0 \\
(0 \%) \\
\end{array}$ & $\begin{array}{c}2 \\
(3 \%) \\
\end{array}$ & $\begin{array}{c}51 \\
(14 \%) \\
\end{array}$ & $\begin{array}{c}7 \\
(7 \%) \\
\end{array}$ & \\
\hline Total & 146 & 222 & 22 & 1 & 82 & 368 & 103 & \\
\hline
\end{tabular}

Table 3: $\chi^{2}$ index for the reactions to the initial conflicts among peers.

1.

2.

3.

4.

5.

6.

7.

8.

9.

10.

11.

12.

13.

14.

15.

16.

17.

18.

19.

20.

21.

$\begin{array}{cccccc}\begin{array}{c}\text { No inter- } \\ \text { vention }\end{array} & \begin{array}{c}\text { Students } \\ \text { solve it } \\ \text { on their } \\ \text { own }\end{array} & \begin{array}{c}\text { Teacher } \\ \text { as a } \\ \text { media- } \\ \text { tor in the } \\ \text { conflict }\end{array} & \begin{array}{c}\text { Students } \\ \text { must say } \\ \text { sorry }\end{array} & \begin{array}{c}\text { They are } \\ \text { being } \\ \text { punished }\end{array} & \begin{array}{c}\text { Bilateral } \\ \text { Sig. }\end{array} \\ & & & \\ \end{array}$

\begin{tabular}{lllllll}
\hline Initial conflict & & & & & & \\
Verbal aggression & $48(27 \%)$ & $23(22 \%)$ & $220(21 \%)$ & $20(26 \%)$ & $62(21 \%)$ & $p=0.001$ \\
Physical agression & $50(28 \%)$ & $26(25 \%)$ & $324(31 \%)$ & $35(45 \%)$ & $111(38 \%)$ & \\
Psychological aggression & $63(37 \%)$ & $36(35 \%)$ & $373(36 \%)$ & $21(27 \%)$ & $78(26 \%)$ & \\
Breaking rules & $14(8 \%)$ & $19(18 \%)$ & $121(12 \%)$ & $2(2 \%)$ & $45(15 \%)$ & \\
\hline Total & $\mathbf{1 7 5}$ & $\mathbf{1 0 4}$ & $\mathbf{1 0 3 8}$ & $\mathbf{7 8}$ & $\mathbf{2 9 6}$ & \\
\hline
\end{tabular}

Table 4: $\chi^{2}$ index for the reactions of the teachers to the initial conflicts among peers.

Teachers and other peers are key to ameliorate and solve these conflicts in schools, creating and potentiating a positive environment and climate in school contexts (Collell and Escudé 2011), through assemblies (Agramunt et al. 2004), specific programmes (Tuvilla 2004) or mediation (García-Raga et al. 2012; Molina 2005). Above all, as many authors have pointed out, conflicts can be successfully resolved and prevented when the implicated individuals receive good management of emotions, that is, successful and efficient management of their social and emotional skills (Greenberg et al. 2003). Therefore, preventive interventions that focus on the training of emotional education can be highly beneficial to avoid conflict situations in schools (Eisenberg and Spinrad 2004; Greenberget al. 2003).

Despite the aforementioned assumptions, conflicts remain present in schools, showing different patterns, and thus, pointing out different underlying emotional training needs. In the present study, we could observe these different patterns,in both students and teachers, which suggests that some intervention at social and emotional levels may be needed.

. 3.




\section{Conflict registration}

According to our results, the highest number of conflicts took place among students that were younger. Although some authors claim that more conflicts can occur among older children (Laursen et al. 2001; Pelegrini and Long 2002), other researchers claim that younger children are more likely to exhibit poor impulse control, low frustration tolerance and limited insight into their own feelings and that of others (Sidorowicz and Hair 2009). Thus, younger children are more easily engaged in aggressive behaviour, which turns, at the same time, into more observable conflicts, as is the case with verbal and physical aggression (Sidorowicz and Hair 2009).

Regarding the sex of students, our results demonstrate that the most number of conflicts occur between boys and girls. This is supported by previous studies in the literature, which explains that more observable conflicts, such as hitting or insulting, are more observed among boys, whereas those conflicts involving girls tend to show behaviour more related to social exclusion (Artavia 2012; Félix et al. 2008).

Reactions of the students to the initial peer conflicts were also explored in the present study. Although few studies have focused on studying this matter, cross-sectional findings indicate that both boys and girls are initially likely to use reactive aggression (Hay et al. 2011). Our results show that aggression tends to be answered with a fresh aggression instead of with a regulated emotional response. However, those peer conflicts that were more related to psychological or verbal aggression did not result in another aggressive behaviour but in the search for help. This can be explained by the possibility that the level of social skills at the ages 6-12 partially mediates the effects of anger reactions. That is, older children, with higher emotional awareness and with more defined social abilities may exhibit more appropriate behaviour when facing an aggression (Eisenberg 1999).

\section{Teacher intervention}

Our results regarding the intervention of teachers during conflicts shed some light on the responses that children get from their educators in conflict situations in the playground. It is interesting that results show that the most applied strategy was the teacher's mediation in the conflict. That may indicate that a mediation training in these schools could be highly beneficial. Additionally, it is important to highlight that data show that most teachers feel unprepared to deal with certain conflicts, although when they intervene they tend to mediate or punish more often, which clearly supports our results (Escámez 2001; Meulen et al. 2003).

It can thus be concluded that, unfortunately, conflicts among peers are still very present in schools and cannot be explained without considering emotional development. Therefore, the implementation of efficient programmes that train and help the learning of emotional competences could be highly beneficial not only for students, but also for those professionals that interact everyday with children in schools, such as teachers and educators.

\section{ACKNOWLEDGEMENTS}

This material is based upon work supported by the RecerCaixa 2013 funding grants. 


\section{REFERENCES}

Agramunt, M., Prats, B. and Vidal, V. (2004), 'El patio, espacio educativo' ('The courtyard, educational space'), Cuadernos de Pedagogía, 332:1, pp. 28-30.

Artavia, J. M. (2012), 'Manifestaciones de violencia explícita o evidente durante el desarrollo del recreo escolar' ('Manifestations of explicit or evident violence during the development of school recess'), Actualidades Investigativas en Educación, 12:2, pp. 1-29.

Basu, A. and Mermillod, M. (2011), 'Emotional intelligence and social-emotional learning: An overview', Psychology Research, 1:3, pp. 182-85.

Collell, J. and Escudé, C. (2011), 'Conductes d'exclusió i maltractament entre iguals al parvulari' ('Behaviours of exclusion and mistreatment between peers in the nursery'), Àmbits de Psicopedagogia, 32:1, pp. 37-40.

Defensor del Pueblo (2006), 'Violencia Escolar: El Maltrato entre Iguales en la Educación Secundaria Obligatoria, 1999-2006' ('School violence: Abuse of peers in compulsory secondary education'), Madrid: Publicaciones Oficina del Defensor del Pueblo.

Del Barrio, C., Barrios, Á., Meulen, K. Van der and Gutiérrez, H. (2003), 'Las distintas perspectivas de estudiantes y docentes acerca de la violencia escolar' ('The different perspectives of pupils and teachers about school violence'), Estudios de Joventud, 62:1, pp. 65-79.

Eisenberg, N. (1999), 'Emotion, regulation, and moral development', Annual Review of Psychology, 51:1, pp. 665-97.

Eisenberg, N. and Spinrad, T. L. (2004), 'Emotion-related regulation: Sharpening the definition', Child Development, 75:2, pp. 334-39.

Escámez, J. (2001), 'Los conflictos en la educación secundaria' ('Conflicts in secondary education'), in S. Peiró (ed.), Primeras Jornadas sobre Violencia en Educación: Perspectivas Interdisciplinares de Explicación e Intervención Pedagógica (First Conference on Violence in Education: Interdisciplinary Perspectives of Explanation and Pedagogical Intervention), Alicante: Club Universitario.

Félix, V., Godoy, C. and Martínez, I. (2008), 'Violencia entre iguales: Resultados de un estudio descriptivo de la provincia de Valencia' ('Peer violence: Results of a descriptive study of the province of Valencia'), Información Psicológica, 94:1, pp. 36-48.

Filella, G. (2014), Aprendre a Conviure (Learn to Live Together), Barcelona: Barcanova.

García-Raga, L., Martínez-Usarralde, M. J. and Sahuquillo, P. (2012), 'Hacia una cultura de convivencia: La mediación como herramienta socioeducativa' ('Towards a culture of coexistence: Mediation as a socio-educational tool'), Cultura y Educación, 24:2, pp. 207-17.

Greenberg, M. T., Weissberg, R. P., O’Brien, M. U., Zins, J. E., Fredericks, L., Resnik, H. and Elias, M. J. (2003), 'Enhancing school-based prevention and youth development through coordinated social, emotional, and academic learning', American Psychologist, 58:6-7, pp. 466-74.

Hay, D. F., Nash, A., Caplan, M., Ishikawa, F. and Vespo, J. E. (2011), 'The emergence of gender differences in physical aggression in the context of conflict between young peers', British Journal of Developmental Psychology, 29:2, pp. 158-75.

Keener, S. and Leaman, D. (2007), 'Understanding and managing student hostility', National Middle School Association (NJ3), Middle Ground, 11:1, pp. 22-23.

Laursen, B., Finkelstein, B. D. and Betts, N. T. (2001), 'A developmental metaanalysis of peer conflict resolution', Developmental Review, 21:4, pp. 423-49.
1.

2.

3.

4.

5.

6.

7.

8.

9.

10.

11.

12.

13.

14.

15.

16.

17.

18.

19.

20.

21.

22.

23.

24.

25.

26.

27.

28.

29.

30.

31.

32.

33.

34.

35.

36.

37.

38.

39.

40.

41.

42.

43.

44.

45.

46.

47.

48.

49.

50.

51.

52. 
Martín, E., Rodríguez, V. and Marchesi, A. (2003), Encuesta sobre las Relaciones de Convivencia en los Centros Escolares y en la Familia (Survey on the Relationships of Coexistence in the Schools and in the Family), Madrid: CIE-FUHEM.

Meulen, K. Van der, Soriano, L., Granizo, L., Del Barrio, C., Korn, S. and Schäfer, M. (2003), 'Recordando el maltrato entre iguales en la escuela: Consecuencias e influencia en la actuación del profesorado' ('Recalling the abuse of peers in school: Consequences and influence on the performance of teachers'), Infancia y Aprendizaje, 26:1, pp. 49-62.

Molina, F. (2005), 'Nuevos conflictos sociales y su presencia educativa: Análisis sociológico y reflexiones para la intervención' ('New social conflicts and their educational presence: Sociological analysis and reflections for intervention'), Cultura y Educación, 17:3, pp. 213-23.

Murray-Close, D. and Ostrov, J. M. (2009), 'A longitudinal study of forms and functions of aggressive behavior in early childhood', Child Development, 80:3, pp. 828-42.

Olweus, D. (1993), Bullying at School: What We Know and What We Can Do, Oxford: Blackwell.

Ortega, R. (2008) (ed.), Disciplina i Gestión de la Convivencia: 10 Ideas Clave (Discipline and Management of Coexistence: 10 Key Ideas), Barcelona: Graó.

Ostrov, J. M. and Crick, N. R. (2007), 'Forms and functions of aggression during early childhood: A short-term longitudinal study', School Psychology Review, 36:1, pp. 22-43.

Pelegrini, A. and Long, J. D. (2002), 'A longitudinal study of bullying, dominance and victimization during the transition from primary school through secondary school', British Journal of Developmental Psychology, 20:2, pp. 259-80.

Rivers, I. and Smith, P. K. (1994), 'Types of bullying behaviour and their correlates', Aggressive behavior, 20:5, pp. 359-68.

Rubin, K. H., Bukowski, W. M. and Parker, J. G. (2006), 'Peer interactions, relationships, and groups', in N. Eisenberg (ed.), Handbook of Child Psychology, Social, Emotional, and Personality Development, v ol. 3., 6th ed., Hoboken, NJ: Wiley, pp. 571-645

Santa, A. (2007), 'The playground as classroom', Educational Leadership, 64:8, pp. $78-79$.

Sidorowicz, K., Hair, E. C. and Milot, A. (2009), 'Assessing bullying: A guide for out-of-school time program practitioners', Research-to-Results Brief, Child Trends, 43:1, www.childtrends.org/wp-content/uploads/2009/10/ child_trends-2009_10_29_rb_assessingbullying.pdf. Accessed 4 August 2017.

Simbulaa, S., Panarib, C., Guglielmic, D. and Fraccarolid, F. (2012), 'Teachers' well-being and effectiveness: The role of the interplay between job demands and job resources', Teacher and Teaching Education, 69:24, pp. 729-38.

Toldos, M. P. (2005), 'Sex and age differences in self-estimated physical, verbal and indirect agression in Spanish adolescents', Aggressive Behavior, 31:1, pp. 13-23.

Tuvilla, J. (2004), 'Convivencia escolar y resolución pacífica de los conflictos: Plan Andaluz de educación para la cultura de paz y no violencia' ('School coexistence and peaceful conflice resolution: Andalusian culture of peace and non-violence education plan'), Consejería de Educación y Ciencia, 6:1, pp. 7-74. 
SUGGESTED CITATION

Ros-Morente, A., Piqué, M. À. C. and Guiu, G. F. (2018), 'Conflicts among peers in the playground in a group of Spanish elementary schools', Portuguese Journal of Social Science, 17:1, pp. 79-88, doi: 10.1386/pjss.17.1.79_1

\section{CONTRIBUTOR DETAILS}

Agnès Ros-Morente, Ph.D., is lecturer of psychology and emotional education at the Department of Pedagogy and Psychology, in the University of Lleida. Her research interests focus in basic emotion processes, as well as emotion regulation and its correlates.

Contact: Department of Pedagogy and Psychology, University of Lleida, Av. de l'Estudi General, 425001 Lleida.

E-mail: a.rosmorente@pip.udl.cat

Maria Àngels Cabasés Piqué, Ph.D., is professor in the Department of Economy and Law of the University of Lleida. Her research interests include politics and conflict solving. She has been involved both in teaching innovation and political tasks in the government of Catalunya.

Contact: Department of Pedagogy and Psychology, University of Lleida, Av. de l'Estudi General, 425001 Lleida.

E-mail:m.angels.cabases@econap.udl.cat

Gemma Filella Guiu, Ph.D., is professor in the Department of Pedagogy and Psychology of the University of Lleida. She is one of the most prominent figures in Spain in the research and implementation of virtual reality methods for the improvement and development of emotional skills in children and adults.

Contact: Department of Pedagogy and Psychology, University of Lleida, Av. de l'Estudi General, 425001 Lleida.

E-mail: gfilella@pip.udl.cat

Agnès Ros-Morente, M. Àngels Cabasés Piqué and Gemma Filella Guiu have asserted their right under the Copyright, Designs and Patents Act, 1988, to be identified as the authors of this work in the format that was submitted to Intellect Ltd.
1.

2.

3.

4.

5.

6.

7.

8.

9.

10.

11.

12.

13.

14.

15.

16.

17.

18.

19.

20.

21.

22.

23.

24.

25.

26.

27.

28.

29.

30.

31.

32.

33.

34.

35.

36.

37.

38.

39.

40.

41.

42.

43.

44.

45.

46.

47.

48.

49.

50.

51.

52. 